\title{
Problematic of Accounting Evolutivity: An Answer Through the Analysis of SYSCOHADA in the Cameroonian Context
}

\author{
Kadouamaï Souleymanou \\ The University of Maroua, Maroua, Cameroon \\ Hervé Ndoume Essingone \\ National Institute of Management Sciences, Libreville, Gabon
}

\begin{abstract}
This article describes the conceptual, practical, and organizational difficulties of evolutivity of a new uniform act. Besides the problem of stock market listing of most African countries enterprises seen among many other things as a prerequisite to the internationalization of accountancy, particularly, to the emergency of the full or total or not at all implementation of an innovation, it is a matter of bringing the foundations into focus. The most expected heated debates on the SYSCOHADA accounting evolutivity in view of the implementation of its new uniform act, of the quality of information provided and the informational pertinence are therefore collected through semi-direct interviews from accountants and auditors. A situational analysis is carried out in the Cameroonian context. From a qualitative approach, the potential constraints are explained. The interest of the analysis of this evolutivity is that, despite its temporal status, it is intimately linked to organizational and social realities.
\end{abstract}

Keywords: uniform act, SYSCOHADA, scalability, constraints, Cameroon

\section{Introduction}

Following evolutionary perspectives of accountancy, the foundations of a total, partial or not at all implementation of an accounting innovation are explained in this article. It intends to describe firstly the subject matter of accounting difficulties of designing, application, and organization related to the implementation of SYSCOHADA since its coming into force in 2001 and its revision in 2017. In fact, Causse and Mandzila (2016) propose a graduated approach, because SYSCOHADA is at a crossroads of continental and Anglo-saxon standards. The fact remains that these debates are enhanced with concrete and real opinions experienced on the difficulties in implementation, so as to take a critical look at advanced choices on standard components to adopt. Opinions enable to accompany the new accounting standards with a number of teachings that are not simply attached to accounting basis, but which also affect the specificities of African organizations in their applicability. This study sides with an approach that enables to progressively discover the realities, instead of having predetermined a priori to confirm or refute.

\footnotetext{
Acknowledgment: Souleymanou and Ndoume Essingone would like to thank all the conference delegates of the 8th African Accounting and Finance Conference organized by the African Accounting and Finance Association from 4 to 7 September 2018 in Senegal (Dakar), for their remarks which have enabled the improvement of this article.

Kadouamaï Souleymanou, Associate Professor, Head of Department of Accounting and Finance of the Faculty of Economics and Management, University of Maroua, Maroua, Cameroon.

Hervé Ndoume Essingone, Full Professor in Accounting and Finance, National Institute of Management Sciences, Libreville, Gabon.
} 
Other studies on the problematic of evolutivity of accounting systems and the pertinence of information (Feudjo, 2010; Souleymanou, 2010; 2011; Ngantchou, 2011; Avele \& Degos, 2014; Souleymanou \& Halidou, 2014; Souleymanou, Djekaye, \& Hikkerova, 2016; Bampoky, 2016; Degos \& Souleymanou, 2016; 2018) in the African context are indicative of a particular interest and important difficulty to the realities of adjusting to International Financial Reporting Standards (IFRS). It seems interesting in the view of continental accounting standards (such as OHADA) to explain the constraints. But it seems more interesting again to elucidate essentially the limits on the imperative OHADA/IFRS since the revision of the uniform act of 15 February 2017. Since then, this continental system of reference has tremendously developed. It has reinforced its pertinence through the new uniform act made compulsory with effect from 1st January 2018. This leads to believe that the mutation OHADA/IFRS firstly brings about an improvement of the pertinence of financial information in relation to the continental reference system without mutation. But any initiative of innovation has consequences.

Furthermore, the adoption of IFRS standards has often been described as an initiative leading to a revolution of financial information in Africa. At least, it represents a deep change for enterprises. The change is clear at the conceptual level, as shown by the choice of the investor as privileged addressee of financial information. International financial markets are more and more of importance for enterprises seeking access to financing sources at the international scale.

In the light of articles 8 and 73-1 of the new SYSCOHADA uniform act, the gradual shift (Causse \& Mandzila, 2016) to standards IAS/IFRS constitutes a real strategic opportunity for enterprises in terms of financial communication. It has been qualified as "cultural revolution" and must be subject to a structured revolution in each group of enterprises concerned and at all the operational levels. It should all the same enable to respond to the expectations and questions of investors in the field of measurement of performance and profitability, of comparability of African enterprises among themselves and at the international level. But it must also be considered as the major project of the two successive years (2018 and 2019) and be the subject of a genuine organization by "project management" so as to analyze and evaluate all the impacts of the adoption of IAS/IFRS standards. The opportunity is thus given to enterprises to review the organization and the provision of financial data by bringing together the elements of management of traditional financial statements and to upgrade the accounting function.

The subject of this study is the analysis of determinants that limit the total implementation of IFRS by enterprises after the revision of SYSCOHADA. From the problematic put forward, this question is broken into: How do audited entities and accounting firms adopt the revised SYSCOHADA in a prospect of convergence towards IFRS? This study is divided into three sections. From the theoretical and practical point of view, the foundations of OHADA accounting evolutivity in Africa are firstly laid (1). Secondly, the constraints of the revision of OHADA accounting system are highlighted. The data and methods of the study are put forward thanks to the interviews for the preparation of efficient transition of African enterprises (3). The results of those efficient evolutionist prospects towards a new OHADA accounting system are discussed (4).

\section{The Foundations of Evolutivity of the OHADA Accounting System}

The popularization and the promotion of accounting norms in Africa are establishing themselves as a necessity in a global liberalized economic context, where only competitive enterprises will succeed at the game. Although Africa hardly represents only $2 \%$ of global exchange, the adaptation to the "new deal" proves to be a 
prime necessity. The globalization of the economy with the dismantling of trade borders causes the enterprises of the sub-region to adapt to a new economic environment, whose competitiveness of enterprises constitutes the cardinal rule. The evolutivity of OHADA (Organisation for the Harmonization of Corporate Law in Africa) constitutes among others a better appropriation of the International Financial Reporting Standards (IFRS), as a rapprochement to these international accounting standards of reference, in force since more than 10 years already (in Europe and in North America). The foundations of SYSCOHADA evolutivity are therefore double: theoretical and practical.

\section{Theoretical Foundations}

In the prospects of the evolutionist theory in accounting (Littleton \& Zimmerman, 1962; Kuhn, 1970; Belkaoui, 1984), the theories mobilized enable to understand the opinions of entities of accounting firms on their predispositions to adapt to the evolution from SYSCOHADA to IFRS. Firstly, the syntactic accounting theory (Hendriksen, 1982) is adopted to explain accounting practices in force, and to enable to predict the reaction of accountants facing some situations, the way of adopting and disclosing events. Then, the inductive accounting theory (Hatfield, 1927; Gilman, 1939; Littleton, 1953) is called to describe the considerable influence of situations in the accounting thought and to state the theory by means of observations and current practices. Finally, the descriptive or positivist theory (Watts \& Zimmerman, 1978) is called to describe the accounting practice by the revelation of its fundamental principles that aim at making people understand what accounting is in the context studied.

In the current context of accounting globalization, African enterprises have more than ever the obligation to take up the challenge. The explanations of the reason of the change of the OHADA uniform act lie in the quality of financial information intended for investors as a priority. It is no longer a matter of presenting the financial statements that obey to the rule of law, which requires the modification of methods currently practiced, if we are referring to an accounting system such as the one of OHADA. The presence of African multinationals is asserting itself in the global economy. It imposes on continental firms to comply with international standards, despite the lightweight of Africa in global exchange.

We are evolving in a liberalized economy. In reality, it is a matter of principle of competitiveness that SYSCOHADA enterprises must integrate, especially if they nurture the ambition to conquer the international market. The direct consequence is that the certification of their accounts in accordance with their new accounting rules, contributes in increasing their credibility facing their international investors. On the basis of financial information expressed in a specific language, they will be able to contribute significantly to the increase of the volume of their capitals. Financial information, as advocated by SYSCOHADA, having a limited scope, the stakes for African enterprises members of that organization would like them to follow the evolution of global economy, despite the consequences of adoption resulting from it.

As perceived by Littleton and Zimmerman (1962), an element of continuity therefore emerges from the changes brought to accounting through centuries of its history and a constant relation is established between accounting developments, circumstances and the needs of a changing society. We are then opposite an evolutive development, though slow, of accounting practice, linked to perceived needs during decades. Therefore, accounting and its paradigms play an essential role in the quest for optimal governance (Degos \& Souleymanou, 2016, p. 66). 


\section{Practical Foundations}

In its practical evolutionist perspective, the revised OHADA does not move towards the keeping of double accounting (article 8, 73-1, and 75), as it is the case in Anglo-Saxon countries. Certainly, it risks depriving countries from the possibility of implementing appropriate fiscal strategies (attraction of investors, town planning or rebalancing of their economies). But in its ambition, it progressively evolves to build a typical financial accounting, while maintaining the prominence of historical cost. The possibility of accounting for an asset or a liability at its "fair value" that is its economic value is measured here from a market price or the estimate of future advantages related to it (in accordance with articles 39, 42, and 63 of the new uniform act and its provisions of page 115, in reference to IFRS 13, published on 12 May 2011).

Furthermore, in its foundations, the uniform act SYSCOHADA (UA) favors standardization to harmonization. It takes form through conventions and accounting principles (besides articles 3, 6, 8, 9, 10, 11, $33,34,35,36,39,40,59$, where there are principles relative to articles 17,35 , and 36 ). It is also characterized by the conceptual framework (elaboration of new standards, article 14). It embodies the mechanism of communication of financial statements (statement of changes in equity, cash flow statements, explanatory notes, and other information).

Let's all the same remind (Degos \& Souleymanou, 2018, p. 49) that SYSCOHADA 2017 is made of 13 titles and 83 chapters (against four titles of seven chapters for the old uniform act of 2000). The TAFIRE is cancelled and replaced by the cash flow statement. Three articles are cancelled $(12,27,60)$ out of 113 which had in total. Two hundred and fifty six accounts and sub-accounts have changed their title, 46 asset accounts are cancelled, 192 liability accounts created, 14 sub-accounts created to facilitate the elaboration of cash flow statement. Among the accounting evolutions mentioned in terms of modifications of AU-SYSCOHADA, we have:

- The use of financial statements (the investor as privileged user of financial statements);

- The objectives of financial statements as for International Accounting Standards Board (IASB) (the general objective of financial statements is to give information on the financial situation of the enterprise and its evolution, in the first position, that is presented by the balance sheet);

- The characteristics of information (communication of financial information);

- The presentation of financial statements (normal system, MTS, financial statements of IFRS standards);

- OHADA is in the age of releasing financial information;

- The decision of releasing financial information in IFRS was taken (since 26 January 2017 in Brazzaville);

- OHADA is a conception of international financial vision shown by the necessity of presenting statements relative to the possibilities of full adoption of IFRS standards, even for a double bookkeeping according to the new uniform act (articles 8, 73-1, and 75) (Causse \& Mandzila, 2016, p. 6);

- Revised OHADA marks an opening of the economy of developing countries and an internationalization of markets;

- The need of international readability in the OHADA zone is expressed (article 73-1 of the new uniform act).

Concerning capital lease, the uniform act of 2001 provides for the accounting of leasing contracts (article 
38) whereas the new OHADA ${ }^{1}$ uniform act provides for the detailed accounting in light of accounting recordings at the date of entry into the heritage, a subsequent accounting, an accounting of specific cases of capital leasing with a purchase option, with the presentation of financial statements of the lessee (balance sheet and profit and loss account). All these accountings are provided for besides the accounting of operating lease, and in leases on a housing complex. We notice that these forecasts are close to IAS 17 standard, which for example makes provision for the accounting of leases targeting any capital lease, whatever the legal form it is invested (Schevin, 2010, p. 20).

For investment securities, or real property detained or not for the needs of exploitation but to collect rents or for transfer, the revised SYSCOHADA advocates an accounting treatment based on an evaluation at historic rate. These principles of accounting evolutivity have constraints.

\section{Constraints Related to the Revision of SYSCOHADA}

\section{Accounting Revision: An Imperative, a Reflection of the Evolution of the Society}

In the European and American society for instance, accounting revealed itself since 7th edition, in 2005. An accounting revolution has established itself in the world, undoubtedly corresponding to the needs of the new financial capitalism, therefore seeking to harmonize the accounting standards of all the countries. It is a reflection of the real evolution of the society. Richard and Colette (2008) talked about a "triple revolution" and a "counter-revolution" of financial accountancy. This phase of the evolution of capitalist accountancy continues and one can summarize its main aspects as follows. As from the end of XX century, the United States have progressively modified their accounting, abandoning (partially) the old accounting in "historic cost" for the benefit of a new accounting in "fair value". Curiously, this accounting revolution that enables to abandon the sacrosanct principles of achievement and presence, established itself whereas the American world was shaken by scandals, especially the one of Enron. Undoubtedly, it corresponded to the needs of the new financial American capitalism, profit-hungry in the short term, even not satisfied. A second revolution occurred shortly after when the organization International Accounting Standards Committee (IASC) (which became IASB in 2002) which seeks to harmonize accounting standards of all the countries (except the United States) had practically decided under the pretext of "convergence", to align the essential of its accounting principles with American rules and especially to take for ideological reference the concept "fair value". Some people have considered that after having shown signs of independence from the American "elder brother" at the beginning of its life, IASC/IASB has become the "Trojan horse" of American standards. The third revolution concerns more specifically Europe. It occurred in 2002 when, by a regulation of the counsel of 19 July 2002, the European Union had not only abandoned any will to continue to build an accounting regulation specific to Europe, but had decided to trust to IASB the care of elaborating standards applicable to the European Union in the field of consolidated accounts (of groups).

In the African society, after the abandonment of 1957 plan, of Organisation Commune Africaine et Malgache (OCAM) plan created in 1970 to adopt the OHADA system with effect from 1st January 2001, accounting does not stop being mirrored in that society, a continuous evolution of innovation and adoption of this accounting system (from 2001 to 2017). It went through different stages (in 2008, 2013, 2014, 2015, and

\footnotetext{
${ }^{1}$ OHADA means: Organisation for the Harmonization of Corporate Law in Africa. The provisions draw on the treatments advocated by IFRS16 international accounting standard published on 13 January 2016, see revised SYSCOHADA uniform act, pp. 624-632.
} 
2017). Nowadays (since 15 February 2017), the parallel adoption of IFRS international reference system is envisaged, especially for listed companies and calling initial public offering.

\section{OHADA Revision, an Organizational and Socio-economic Constraint}

The revision of the OHADA uniform act and the organizational context. The taking into consideration of the organizational context in which accounting operates is historically the first of the contributions among which we call upon the ones of Hopwood (1972; 1973; 1974). These "Hopwoodian" contributions have been later on answered by Otley (1978), and gave birth to a research current structured under the Reliance on Accounting, Performance Measures. These authors highlight the dysfunctional nature of accounting (particularly within the budget framework). Many sources of dysfunctioning issued from the organizational context of Accounting are highlighted by Hopwood (1972; 1974):

- Any pertinent information is not always included in financial reports.

- The cost function is never known with the necessary precision and accounting only reflects the complexity of the organization.

- Accounting is only interested in results whereas managers are interested by the details of the process that enable to arrive at the results measured.

- Accounting puts a lot of emphasis on short term data whereas managerial performance must be measured by taking the long term into consideration.

These worries are felt in the SYSCOHADA accounting audit. Therefore, there exists a paradox between the dysfunctional nature of an accounting system and the uncertainty that it permits to reduce in an accounting model of national or continental type. The way of using figures is then most important as mediating variable in this type of appropriation and presentation of accounting. It is important to understand well that in the African context, the adoption of the revised OHADA accounting has two distinct meanings. The first one is the one of social and legal accounts which must correspond to the fiscal legislation of the country where the company is based. The second one is the one of accounts in the sense of consolidation of an entity or group, which are published for the information of the investor and that another partner company must know. Their presentation is linked to the social context.

Accounting matching SYSCOHADA and the socio-economic context. Besides organizational and behavioral constraints, accounting matches the social and economic dimensions. Accounting is also adopted as a rite. Its development is therefore linked to the social context of SMSE (Small and Medium Size Enterprises) (which constitute the majority of African enterprises) and big companies. It can therefore be said that accounting is influenced as well as it influences the context (Hopwood, 1983). Its change contributes to the definition of organizational purposes, but social and political provisions will have to change. In such a context, accounting appears as a point of tension between economic considerations and social considerations.

At the social level, the sociocultural environment of the OHADA space relative to financial information to publish according to the new uniform act is a determinant factor for the development of enterprises, particularly for the applicability of its articles 8 and 73-1 relative to International Financial Reporting Standards (IFRS). The spirit of these articles orientates the production and the dissemination of information to investors, therefore, the opening of capital. In Africa, from the social point of view, the manager owner prefers keeping his capital closed by limiting himself to his small family when he feels the necessity of delegating responsibilities within the company. Therefore, the cultural environment influences the enterprises which have not yet understood the 
importance of accounting in their management. They move towards that function in the unique perspective of paying their fiscal obligations. These aspects represent the obstacles to the smooth running of the accounting profession in such a context.

Hopwood studies (1987) show in a context different from Africa that diversities in national accounting practices are the combined effect of factors that surround the accounting environment as the requirements of legal declarations and many other variables (national system of appropriation and financing, colonial heritage, tax system, inflation, level of education, age and size of the accounting profession, stage of economic development, legal system, culture, history, geography, language, influence of theory, political systems, social climate, religion).

Answering this preoccupation supposes defining beforehand the notion of quality of financial information. According to Lenormand and Touchais (2009), the most developed thinking goes to Financial Accounting Standards Board (FASB) (Jonas \& Blanchet, 2000; Schipper \& Vincent, 2003) which, in its conceptual framework (SFAC no. 2) quoted by IASB, defines the criteria of quality of financial information. These criteria are very significantly adopted by the new OHADA uniform act. It is the reason for the contribution of articles 8 and 73-1. The American normalizer considers that an accounting piece of information is useful for the user for his decision-making if it respects the following criteria: pertinence (information that can make the difference in terms of decision-making by enabling to do, in time, predictions or to confirm/correct past evaluations), reliability (data exempted from errors, neutral and exhaustive leading to a faithful representation of the situation), comparability (in time and space), and intelligibility ${ }^{2}$ (assertion contained in financial statements, whose validity the auditor wants to confirm, that is information provided is presented and described in an appropriate manner and that it is clearly communicated).

From the economic point of view, in reference to IFRS international standards, the OHADA environment relative to financial information to provide and disseminate is an influential factor. Member countries of OHADA are constituted of many economic structures but mainly SMSE localized on the overall extent of the territory although at the national level, the report on the situation of the informal sector presents 165,380/203,419 SMSE which do not keep a written and formal accounting (RGE ${ }^{4}$, 2018, pp. 24-26). Yet, they constitute one of the essential vectors in the economies of the context studied. These statistics represent an important momentum on the perspective of accounting convergence of SYSCOHADA with IFRS standards. Thus, contrary to big enterprises which are mainly located in big cities, SMSE participate to a balance of industries in African countries in general. In fact, a tightly knit social fabric of SMSE well distributed in the regions of countries enables to maintain the communities on the spot and to preserve the balance of cultures, of stability by disseminating certain diversity in the entire milieu. Similarly, SMSE give certain stability to the economy insofar as their number increases or reduces more easily, so as to maintain some stability. The reality of SME in the field of keeping accounting is that those enterprises are in their majority in the informal sector, and the practice of the simple income and spending accountancy is not even ensured there (Penouil, 1998; Hernandez, 1999; Benjamin \& Mbaye, 2012; Degos \& Souleymanou, 2018).

\footnotetext{
${ }^{2}$ According to Menard dictionary (2006), on the one hand, the assertion relative to the comprehensibility implies, for example, that accounting methods chosen by the entity are clearly described and that the information provided about them are not likely to be subject of interpretations significantly divergent by receivers. On the other hand, the intelligibility is an assertion relative to comprehensibility falls under the category of assertions relative to the presentation and information provided.
} 


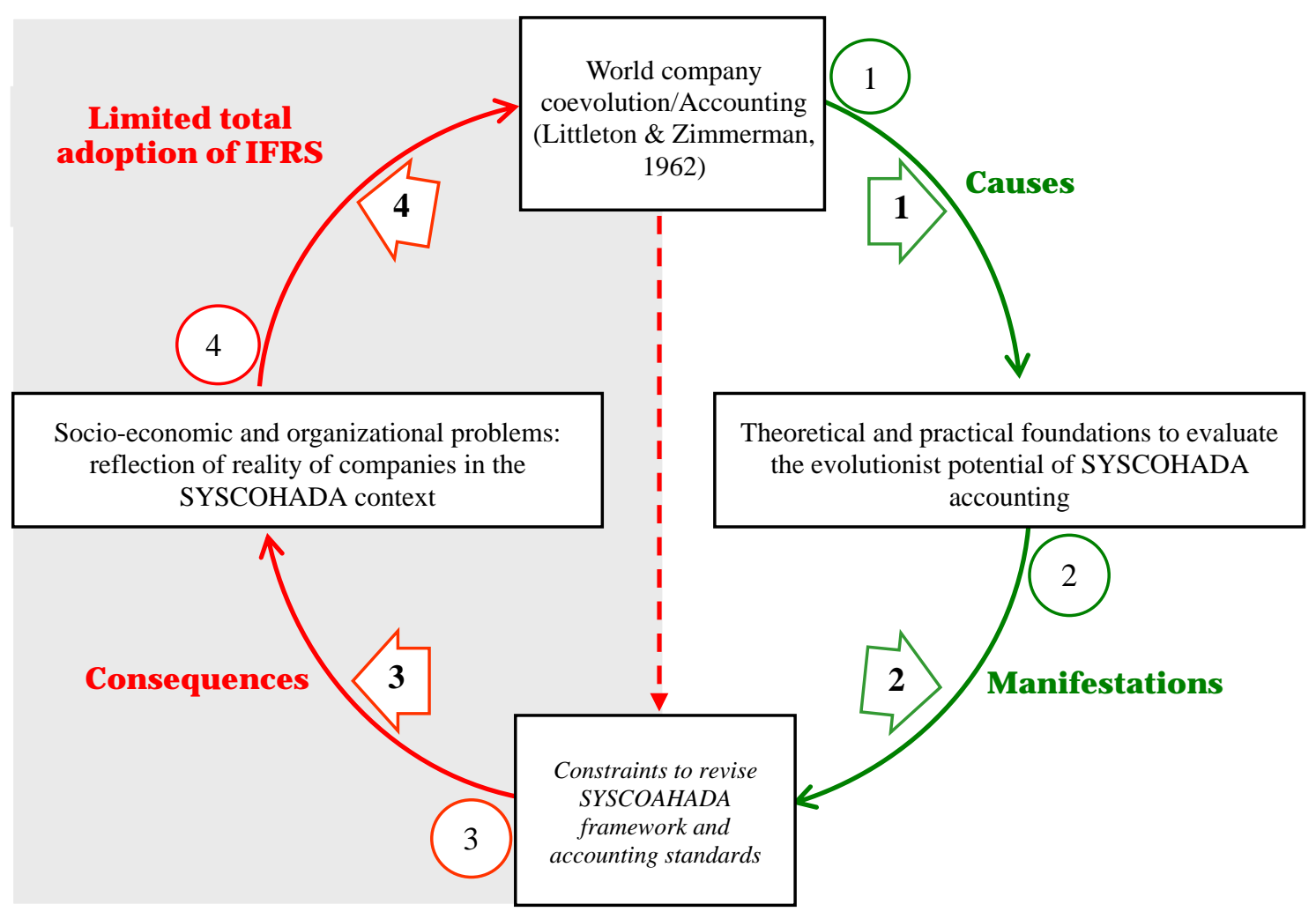

Figure 1. Evolution and accounting matching SYSCOHADA in socio-economic context.

In such an environment and context, the full implementation of the revised uniform act, close to international IFRS standards, is carried out by multinationals or listed companies for reporting needs. Closely held corporations do not implement them through for lack of culture because these standards seem to be interesting only for companies listed on a stock market. According to Burchell, Clubb \& Hopwood (1985, p.382), "However, although a social challenge to accounting thereby was recognised. Most of this literature accepted both the fact of social change and its relevance to accounting, seeking primarily to change and reform accounting in the name of its social context”. Thus, adopted in its social context, accounting is like a cycle. It influences its context as it is influenced by this context.

\section{Population, Data, Methodology, and Answers of the Study}

The population studied is made of on the one hand managers and entity accountants on the other hand, and auditors exercising on the Cameroonian territory. Ten enterprises and ten accounting firms have answered our questions. They are mainly companies on which weights the obligation of certification of financial statements by a legal auditor. From this, we have mobilized the executives of the accounting and financial services to answer the problematic of accounting evolutivity. The interview guide has been elaborated following the literature review, of which a pre-test has been realized with the managers and accounting professionals. The objective of the interview guide was to explain the process of provision of accounting information within accounting firms and enterprises through three themes relative to accounting predispositions of the manager, the constraints of the new uniform act, and the existence of resources (material and human) that enable its implementation. Thus, the opinions of managers, accountants, and experts are collected for the presentation of financial statements after the revision of the uniform act. 
The exploratory investigation carried out on the field has benefited from the favor of company accountants and auditors who had accepted that we should go about this study. Thanks to these semi-direct interviews, the information collected is specific to the accounting and financial domain in a way that it draws from them the maximum of the possible content and processes it.

\section{Choice and Justification of Cases}

In order to choose participants, we have used the purposeful sampling. To this effect, 20 interviews have been carried out in the city of Douala (the economic capital and metropolis of enterprises in Cameroon) in which we can find the strong concentration of auditors and company accountants of various sectors of activity. The processing of the data collected has been done with the software for the analysis of quantitative data (sphinx).

In fact, for a reliable study, the number of cases chosen is determinant. Debates fuelled by authors on this topic are many. Many authors (Dyer \& Wilkins, 1991; Eisenhardt, 1989; 1991; Rispal, 1993; Yin, 1994; Labelle \& Touron, 2001) advocate resorting to a number of cases. Firstly, Dyer, and Wilkins (1991) think that the study of a unique case is explained by the presentation of the particularity of a context likely to increase the value of demonstration. For that reason, we advocate resorting to 10 cases, in order to vary the contextual characteristics. Ten cases are studied for managers and company accountants and ten cases are also chosen for auditors.

The cases studied in this work are 20 in all, among which 10 company accountants. This sample has been constituted according to a convenience approach. The sampled companies have been selected on the basis of accessibility and the availability of managers but also on the basis of their respective sectors of activity in order to have some representativeness in the sample obtained finally. Accountants and auditors accepted it with mistrust because they thought they would fall in the trap of tax officers before we restored confidence in them. The cases chosen are presented in the following table.

Table 1

Presentation of Cases

\begin{tabular}{|c|c|c|c|}
\hline Sector of activity & $\begin{array}{l}\text { Date of } \\
\text { interview }\end{array}$ & $\begin{array}{l}\text { Duration of } \\
\text { the interview }\end{array}$ & Profile of the sample \\
\hline Case 1 , trading & $22 / 09 / 17$ & $108 \mathrm{mn}$ & $\begin{array}{l}\text { One-person limited liability company with a capital of 3,500,000 made of } 3 \\
\text { branches situated in Douala (headquarters) Yaoundé and Bafoussam. } \\
\text { Limited liability company with a capital of } 10,000,000 \text {. This company is based in }\end{array}$ \\
\hline Case 2, trading & $22 / 09 / 17$ & $95 \mathrm{mn}$ & $\begin{array}{l}\text { Douala. It sells motorcycles that it buys as such. It has } 10 \text { branches among which } \\
\text { one in each region. It has an accountant in each branch but everything is } \\
\text { centralized in Douala. }\end{array}$ \\
\hline Case 3 , service & 22/09/17 & $98 \mathrm{mn}$ & $\begin{array}{l}\text { Limited liability company with a capital } 1,000,000 \text {. It is an interim branch only } \\
\text { based in Douala. It has an accountant who takes care of all the operations. }\end{array}$ \\
\hline Case 4 , trading & 23/09/17 & $101 \mathrm{mn}$ & $\begin{array}{l}\text { Limited liability company with a capital of 5,000,000. It sells high-end household } \\
\text { equipment represented everywhere in Cameroon. }\end{array}$ \\
\hline Case 5, industry & 23/09/17 & $98 \mathrm{mn}$ & $\begin{array}{l}\text { Limited company with a capital of } 100,000,000 \text {. It makes body oil and perfumes. } \\
\text { It has three representations in Cameroon: the Littoral, the Centre, and the West. In } \\
\text { each representation, the accountant gives account to the accountant in Douala } \\
\text { each weekend. }\end{array}$ \\
\hline Case 6, trading & 23/09/17 & $84 \mathrm{mn}$ & $\begin{array}{l}\text { Limited liability company with a capital of } 1,000,000 \text { essentially based in Douala. } \\
\text { Big shopping centre with two accountants and a director. }\end{array}$ \\
\hline Case 7, industry & $24 / 09 / 17$ & $100 \mathrm{mn}$ & $\begin{array}{l}\text { Limited liability company with a capital of } 8,000,000 \text {. It makes food products for } \\
\text { animals. It has } 5 \text { branches in the country including the headquarters in Douala. }\end{array}$ \\
\hline
\end{tabular}


(table 1 continued)

\begin{tabular}{|c|c|c|c|}
\hline Sector of activity & $\begin{array}{l}\text { Date of } \\
\text { interview }\end{array}$ & $\begin{array}{l}\text { Duration of } \\
\text { the interview }\end{array}$ & Profile of the sample \\
\hline Case 8, industry & 24/09/17 & $90 \mathrm{mn}$ & $\begin{array}{l}\text { Limited liability company with a capital of 5,000,000 making natural fruit juice } \\
\text { distributed over the national territory. It has } 3 \text { regional branches: the Far North, } \\
\text { the Centre, the Littoral, the North-West and the South-West. }\end{array}$ \\
\hline Case 9, services & 26/09/17 & $85 \mathrm{mn}$ & $\begin{array}{l}\text { Limited liability company specialized in construction and public works, with a } \\
\text { capital of 15,000,000 based in Douala, with a representation in Yaoundé. }\end{array}$ \\
\hline Case 10 , service & 26/09/17 & $90 \mathrm{mn}$ & Establishment with a capital of 1,000,000 specialized in cleaning big buildings. \\
\hline Case 11 , service & 26/09/17 & $88 \mathrm{mn}$ & $\begin{array}{l}\text { Accounting firm, audit board with more than } 20 \text { years of service. Many entities in } \\
\text { its portfolio. }\end{array}$ \\
\hline Case 12 , service & 26/09/17 & $80 \mathrm{mn}$ & $\begin{array}{l}\text { Audit firm based in Douala but attends to enterprises all over the national territory } \\
\text { and even abroad. Its manager masters all the stages of the evolution of accounting } \\
\text { in Cameroon. }\end{array}$ \\
\hline Case 13 , service & 26/09/17 & $98 \mathrm{mn}$ & $\begin{array}{l}\text { Accounting firm represented in Douala and Yaoundé. Its manager takes part in } \\
\text { his capacity as consultant to upgrading seminars on OHADA accounting system. }\end{array}$ \\
\hline Case 14 , service & 26/09/17 & $91 \mathrm{mn}$ & $\begin{array}{l}\text { Accounting firm newly installed in Douala by an expert. It has been assisting a } \\
\text { good number of enterprises based in Douala for two years. }\end{array}$ \\
\hline Case 15 , service & 24/09/17 & $102 \mathrm{mn}$ & $\begin{array}{l}\text { Accounting firm among the oldest auditing firms of the city. Its manager knows } \\
\text { the Cameroonian accounting environment at the finger tips. }\end{array}$ \\
\hline Case 16 , service & 24/09/17 & $85 \mathrm{mn}$ & $\begin{array}{l}\text { Young accounting firm, made of a group of young experts who came back to the } \\
\text { country. They are at the centre of many training sessions on the new uniform act. } \\
\text { Accounting firm present in the city since two decades. Knowing well the }\end{array}$ \\
\hline Case 17 , service & 24/09/17 & $98 \mathrm{mn}$ & $\begin{array}{l}\text { Cameroonian accounting environment, it has a big portfolio of companies that it } \\
\text { assists. Hence its capacity to easily express itself on the reality of SMSE of the } \\
\text { country. }\end{array}$ \\
\hline Case 18 , service & 25/09/17 & $88 \mathrm{mn}$ & $\begin{array}{l}\text { Accounting firm created at the eve of the implementation of the OHADA uniform } \\
\text { act. It has witnessed all the revisions with the enterprises that it assists. }\end{array}$ \\
\hline Case 19 , service & 25/09/17 & $98 \mathrm{mn}$ & $\begin{array}{l}\text { Based in Douala and Yaoundé, this firm has been overseeing enterprises for more } \\
\text { than } 15 \text { years. It organizes trainings and has a good global view of the level of } \\
\text { Cameroonian accountants. }\end{array}$ \\
\hline Case 20, service & 25/09/17 & $109 \mathrm{mn}$ & $\begin{array}{l}\text { This accounting firm is among the oldest in the country. Its manager is of the old } \\
\text { school and has a good knowledge of the environment in the field of accounting } \\
\text { production. }\end{array}$ \\
\hline
\end{tabular}

Our sample is made of 13 service companies among which 10 are audit accounting firms and three other service companies, three industrial companies, and four commercial companies. The choice of the companies is made on the basis of the existence of an accounting service. The choice of auditors is made on the basis of the assistance of at least 10 companies for the follow up of their accounting work.

Table 2

Opinions on the Adoption Capacity of the OHADA Revised Uniform Act

\begin{tabular}{llll}
\hline Capacities & Technical and human & Material & Manager's will \\
\hline Answers & 4 & 4 & 3 \\
Yes & 16 & 16 & 17 \\
No & 20 & 20 & 20 \\
Total & & 20 & \\
\hline
\end{tabular}

At the end of the interviews, it was clearly noted that 7 enterprises out of 10 declare that they are not ready to face the implementation of the OHADA new accounting standards on 1st January 2018. The 10 auditors are unanimous that the enterprises are not ready, as shown by the statistics summarized in Table 2 above and Table 6 in the annex. Out of 20 interviews, the answers of individuals to the questions asked gave us the following results: 4 respondents out of 20 think that, Cameroonian SMEs are ready from the technical point of view to face on 1st January 2018 the implementation of the new uniform act. As far as the availability of technical tools 
within the enterprises is concerned, four people again think that the enterprises have the necessary tools for a good accounting practice. For the last theme on the willingness of enterprise managers to implement the uniform act in their enterprises, three people interviewed answer yes for the human and technical capacities of enterprises to face accounting change.

\section{Collection, Coding, and Retranscription of Interviews}

Data collection was done by the recording on a memory card with a telephone. The retranscription itself took us in total 37 to 40 hours of work. Retranscriptions are subject of an average of five to six pages per case. Many rereading have been done by us and also by the interviewees who made important precisions in order to fine-tune data from the field.

In accordance with our research question, this qualitative method of analysis has enabled us to exchange with professional practicing accountants who work in enterprises as well as auditors. Chosen according to reasoned process, the interviews have enabled us to capture the information sought through the linguistic structure, because the manner the interviewees answer can give a precise meaning to all the discourse that has been the subject of an individual cartography. Once compiled, it enables us to bring out the concepts that we have mobilized throughout our work. The way they deliver their discourse enables to make a coding. We determine primary data provided by verbatim passages and the secondary data which are more abstract concepts developed during the coding of the interviews. Our approach is the one adopted by Gioia, Corley, and Hamilton (2013). We put it in a table that shows us the structure of the data after coding with verbatim passages of our primary data codes in the one of the second. It is a matter of defending the interpretation of our results organized by themes.

From the coding carried out, essential elements are provided for accounting information and its link with the elements that influence it. That is how we have the quality of accounting information opposite the technical level of the accountant, the tools put at his disposal to go about his task. The synthesis comes clearly out below.

Table 3

Summary of General and Secondary Observations

\begin{tabular}{|c|c|c|c|c|}
\hline General observations & Secondary observations & Concepts & Indicators & Manifestations \\
\hline \multirow{3}{*}{$\begin{array}{l}\text { The enterprises are not } \\
\text { ready to adapt to the } \\
\text { accounting evolution } \\
\text { (OHADA new uniform } \\
\text { act and IFRS } \\
\text { international standards) } \\
\text { in due date (on 1st } \\
\text { January 2018). }\end{array}$} & $\begin{array}{l}\text { Is the accounting staff } \\
\text { technically trained and } \\
\text { ready? }\end{array}$ & $\begin{array}{l}\text { Competence and } \\
\text { quality of accounting } \\
\text { information }\end{array}$ & $\begin{array}{l}\text {-Level of education } \\
\text {-Professional experience } \\
\text {-Practical knowledge } \\
\end{array}$ & $\begin{array}{l}\text { Manifestation of the } \\
\text { technical capacity of } \\
\text { accountants }\end{array}$ \\
\hline & $\begin{array}{l}\text { Do accountants have at } \\
\text { their disposal the } \\
\text { necessary resources } \\
\text { (equipment)? }\end{array}$ & $\begin{array}{l}\text { Necessary material } \\
\text { resources }\end{array}$ & \begin{tabular}{|l|}
-Manual of procedure \\
-Update documentation on the \\
evolution in the accounting \\
practice \\
-Automatic management tool \\
of accounting information \\
\end{tabular} & $\begin{array}{l}\text { Manifestation of the } \\
\text { availability of } \\
\text { necessary equipment }\end{array}$ \\
\hline & $\begin{array}{l}\text { Do company managers } \\
\text { have the willingness to } \\
\text { adopt the new uniform } \\
\text { act? }\end{array}$ & $\begin{array}{l}\text { Managers' willingness } \\
\text { to give a true picture } \\
\text { of their company }\end{array}$ & \begin{tabular}{|l|}
-Development of the \\
accountant's capacities \\
-Refresher courses \\
-Evaluation of performances \\
- Working environment
\end{tabular} & $\begin{array}{l}\text { Manifestation of the } \\
\text { manager's willingness } \\
\text { to produce information } \\
\text { in accordance with the } \\
\text { regulation }\end{array}$ \\
\hline
\end{tabular}

The accounting information intended for decision-making must be pertinent, exhaustive, neutral, published in a timely manner, and free from significant anomalies. It thus goes without saying that, in order to provide useful accounting information, it is necessary to follow a rigorous process that enables to ensure that all these criteria are fulfilled. The production process also calls on the professional judgment as far as the 
implementation of standards is concerned, including judgment for the establishment of annual accounts. This aspect is determinant in the provision of reliable, pertinent, and sincere information.

\section{Procedure of Processing Data Collected}

The data processing leads to a set of findings or results that we have analyzed with greatest care thanks to sphinx computer program. Analyzing these results through a case study is done more on opinions than on statistical methods. It is a matter of gathering data in a format easy to manage and construct a text around it. Thereafter, the empirical analysis is carried out after the tendencies of orientations and feelings. Our cases studied are based on opinions received and conceived to induce a questionnaire in the perspective of continuity. The approach therefore consists in analyzing the capacity of Cameroonian enterprises to adopt the reforms of the uniform act applicable on 1st January 2018. In terms of the quality of accounting information given by these enterprises, we will firstly appreciate the current state of the accounting information system of these enterprises, then, see the way they are getting ready. This will enable us to clearly express ourselves on their aptitude to face this accounting "recent deal".

\section{Results, Discussions, Propositions, and Managerial Perspectives}

The adoption of a policy of production of financial information comes from the fact that, for various reasons, the managers of the enterprises decide to conceal the information of their companies. Although in compulsory circumstances, some reasons push them to act in one way or another. The study of factors that push managers to adopt a policy of management of their bookkeeping has been the subject of many theoretical and empirical studies. These studies show that accounting management can be the answer to many objectives (Cormier, Magnan, \& Morard, 1998): the minimization of political costs, the minimization of financing costs, and the maximization of managers' wealth. Moreover, a low level of accounting and/or stock market performance can lead to various strategies of management of accounting results. With the advent of the revision of the OHADA uniform act whose implementation is compulsory for enterprises, the results of the verbatim are obtained.

\section{Results of Verbatim According to the Orientation and Feelings in Enterprises}

Negative feelings. From the predispositions analyzed within the entities, negative opinions are collected. They are specific verbatim retranscribed according to opinions, orientation, and feelings of accountants and company managers. In fact, the production of quality information is explained firstly by the competence which, in itself, is essentially described by the level of education of the accounting staff working within the enterprises. It is manifested by the level of education that can be secondary school, university or any other vocational training or any other experience acquired on the field. Realities are revealed on the field of study carried out in this context.

Obviously, accounting predispositions seem not to be the ones expected. They imply that the technical abilities and even financial means are not yet those which would be able to meet the expectations of adoption of the "new accounting deal" on 1st January 2018, also given that the level of information and knowledge to provide is close (often similar) to the one of IERS international standards.

To the question whether we will be really autonomous and capable of implementing the new norms of OHADA uniform act and even the IFRS standards on 1st January 2018, “I say no” because we are already at three months, at a term of the end of the financial year, we don't have any information on what has been added or what has been changed or 
modified in OHADA uniform act. Moreover, I don't know and I will not know how we will also be able to be at the level of information as the other competing enterprises of other developed countries. I think that in three months, we cannot master the new OHADA uniform act. In the field of change of the OHADA uniform act itself, company managers don't have the intention of giving clear information [...] I don't think that by 1st January 2018 we will be ready [...] Many things are still to be done.

For companies of the regulated sector, D'Souza (1998) shows that on the occasion of a compulsory change of method, the answers of accountants are carried out in accordance with the hypothesis of political costs. Therefore, researches testing the hypothesis of political costs seem to indicate that it is verified for companies that evolve in some contexts of economic, political, or commercial tension. The manager's will of giving a true picture of his enterprise is also an important factor of the quality of accounting information because his action can push the accounting personnel towards an improved service provision. This action is manifested by a policy of capacity development of the accounting personnel through refresher courses, registration to seminars, and particularly the good working environment (conditions). Within this framework, the readiness showed by potential investors at the end of the new accounting practices places managers under pressure when it is time to present financial statements. In this particular context, Parfet (2000) believes that managers are influenced in their decisions and this, even if they try to assume their responsibilities with integrity. Moreover, as far as payments of managers are partially linked to performance, there exists a direct incentive to shape this performance by mechanisms of adoption or accounting choice. The consideration granted to the adoption of the new uniform act therefore seems to confirm the accounting political impact of managers.

Here, we did not make any provision for money for this kind of service provision. It is an audit firm that keeps our accountancy. You know what we experience in our private sector [...]. To tell the truth, it is too tight and too soon to require accounting documents to be produced according to the new uniform act. We need some more time for transition.

Obviously, the feelings expected from accountants and managers are not all negative. Some are positive.

Positive feelings. Some positive opinions are collected. In the capacity building process of workers, the challenge lies in the development policy of human resources. This observation implies that there is a chance for enterprises to have a well trained staff and in accordance with the evolution of accounting practice.

More often, the enterprise is not informed about the evolution of the accounting system because of lack of training and refresher seminars which are not put at our disposal (the employees) by our chiefs. However, you just have to put the means to do it. [...] I can say that there is hope; we will be able to adjust by the deadline. I for instance, registered on OHADA site, and it keeps me aware of the change and thus of the adoption of the OHADA and IFRS uniform act [...]. The work atmosphere is good on the whole. We sometimes have seminars and we all the same participate in some training. As far as equipment is concerned, we don't have enough but everyone wants to improve.

An updated documentation on the accounting practice as the one of the former revision would enable the accountant to prepare and be acquainted with various changes, to make proposals to his hierarchy for keeping the accounts in accordance with regulation. The lack of working tools seems to be the factor that discourages and does not contribute to the production of quality information.

\section{Results of Verbatim According to Orientations and Feelings of Accounting Firms}

The position of auditors in relation to the capacity of enterprises to face the implementation of the new OHADA uniform act and IFRS standards on 1st January 2018 is addressed here according to the different axes subject to the interview in order to collect opinions. Their opinions as external observers are important because 
they are key actors of the daily support of the company. We have collected pessimistic and optimistic testimonies in the interviews.

Opinions of pessimistic auditors. This question really gives the possibility of expressing worries. Nowadays, there are means to train correctly. There is also the opportunity to see the evolution of accounting, whereas feelings are not promising. Certainly, the automatic management tool (accounting applications) is not yet popularized in enterprises. But the challenge is no longer at the level of technical capacities. For that reason, enterprises have personnel who do not have the necessary technical level and the capacity of adaptation that enable them to acquire that knowledge easily. This is disturbing at the technical level because, letting them be the most qualified or the less qualified, their recycling remains capital. Beyond the knowledge necessary to do the work, there are concerns at the level of equipment that enable them to do their tasks correctly.

You know, even if essential things for a good accounting practice are not given, it is not the updated documentation that will be given to accountants. I will not talk about the ill will of managers to do in such a way that the financial information of their business be clear [...]. Sincerely, by 1st January 2018, given the time that remains and the problems that we have to solve, I don't think that enterprises and most particularly our SMSE will be ready. The enterprises with which I work do not make available to their accountants the necessary tools that enable them acquire documentation and develop. Furthermore, managers are less open to the registration of their personnel to seminars or various training enabling the increase of the quality of performance by their staff. Now, working conditions constitute an important factor that can motivate or not the accounting personnel in their work.

Some inexperienced accountants still with no necessary tools are found. Many of them do not have, some have the minimum, but don't use them really. At the level of computer equipment, there are still many limits. We notice that the question on the level of company accountants remains on the agenda because there is a great need to make them intervene in many refresher or training seminars. Many accountants being neither trained nor informed on the evolution of accounting practice, little is hoped from their aptitude to change when time comes, to produce information in accordance with the requirements of the OHADA new uniform act and IFRS. Some managers demonstrate a general lack of willingness because they are the people to decide on the organization of their company for a good production of accounting information.

Furthermore, addressing correctly accounting change is a matter of setting up concrete actions such as a reorganization of accounting service. But we notice that in other cases, great hope is reserved for accounting firms. Operations of the same kind are carried out, leaving us experience that, although at the level of internal organization a lot of achievement is left to be done, the challenge can be taken up by chartered accountants.

Opinions of optimist chartered accountants. If this mutation is the best, it will be nevertheless difficult because there is still a little way. Equipment developed on the spot is generally implemented in relation to the need and the level of acceptable material in comparison with developed countries (Europe for example). Presently, enterprises are not ready to face the implementation of the new OHADA uniform act on 1st January 2018. This is confirmed by the lack of will of managers to recycle their accounting staff and equipment, in brief, they are orchestra conductors. If they don't decide, nothing will be done. Work equipment is to be acquired particularly within SMSE that make the essential of the economic tissue of the OHADA zone. They are not big enough to have the essential to do the necessary accounting work. These are non-negotiable conditions.

For me, company managers have the will and they have no other choice. It is the law; in fact, they have the good will to adjust. It is just the fear to open and to expose themselves to the high fiscal and social pressure that makes in such a way that they conceal their good figures. Many people see in that evolution a means of creating a place in the big business 
community. They are aware of what it creates as information quality. [...] If we have to judge the level of accountants in the companies that I oversee, I will say that I have found some well-equipped accountants from the point of view of training. They have a good foundation and that is interesting. You know, when the foundation is good, we can adapt to the change that intervenes in the environment. For the tool, I think that within enterprises, each person finds its balance in relation to his need and really, if they ask to use an accounting package obligatorily, contractors will complain. But nevertheless, they will, given the potential of their accountant [...]. As far as managers' will is concerned, they will, as I said it, they have no choice. Law is law.

The situation appears to be so reassuring and disturbing because accountants within the enterprise do not seem to be all ready, in light of their level of education for some of them and for others, despite the high level of education, there is the inability to achieve on the field the tasks expected from them without being recycled or trained in this area. This is more linked to lack of professional experience, and on the whole, "a hard road lies ahead". In addition to the foregoing, the questions on equipment in enterprises leave us far from what enterprises should have to be capable of providing good quality information at due date.

\section{Synthesis of Results of Orientation and Feelings of Respondents}

The results of our qualitative analyses are generated by means of "Sphinx Quali" software. The empirical results from the analyses of interviews are presented by highlighting specifically the relation between the implementation of OHADA uniform act and IFRS international standards in the enterprises.

Table 4

Synthesis of Orientations of Responses and Feelings

\begin{tabular}{|c|c|c|c|c|c|c|}
\hline $\begin{array}{l}\text { Orientations and } \\
\text { feelings }\end{array}$ & Number & $\%$ & Average length & The five specific words & Specific context & $\begin{array}{l}\text { Relative wealth } \\
\text { index }\end{array}$ \\
\hline $\begin{array}{l}\text { Significantly } \\
\text { positive }\end{array}$ & 5 & 25 & 47 & $\begin{array}{l}\text { accountant, change, accounting, } \\
\text { documentation, bon ... }\end{array}$ & & 0.90 \\
\hline Rather positive & 5 & 25 & 43 & $\begin{array}{l}\text { accountant, good, information, } \\
\text { manager, level ... }\end{array}$ & & 0.87 \\
\hline Shared & 4 & 20 & 59 & $\begin{array}{l}\text { accountant, chief, training, average, } \\
\text { thing ... }\end{array}$ & $\begin{array}{l}\text { interview with } \\
\text { Case } 12\end{array}$ & 1.13 \\
\hline Rather negative & 4 & 20 & 67 & $\begin{array}{l}\text { enterprise, lack, ready, tool, } \\
\text { willingness ... }\end{array}$ & & 1.21 \\
\hline $\begin{array}{l}\text { Significantly } \\
\text { negative }\end{array}$ & 1 & 5 & 74 & $\begin{array}{l}\text { act, uniform, change, information, } \\
\text { standard ... }\end{array}$ & & 1.21 \\
\hline Without opinion & 1 & 5 & 28 & $\begin{array}{l}\text { act, enterprise, training, standard, } \\
\text { new ... }\end{array}$ & $\begin{array}{l}\text { interview with } \\
\text { Case } 19\end{array}$ & 0.61 \\
\hline
\end{tabular}

This synthesis highlights specific words, specific context and relative wealth index of orientations and feelings of responses. The concepts corresponding to the two axes are explained by the richness of the corpus that constitute the number of words, therefore if the wealth index is superior to 1 , then the responses of that category are richer than the average. Conversely, the less rich responses of that category predict that the average of the index is inferior to 1 . On reading the characterization according to the orientations and feelings, the results of Table 2 above, those of Table 4 above, and those of Table 5 in the annex show that the opinions expressed are: "firstly significantly negative (74 words reiterate it, particularly: uniform act, change, information, IFRS standards) expressed by the cases studied; then, they prove rather negative (67 words express it, particularly: enterprise, lack, ready, equipment, willingness); finally, they are shared (59 words prove it, among which particularly; the words accountant, chief, training, average). Respective wealth indexes superior to 1 are $1.21 ; 1.21 ; 1.13$. 


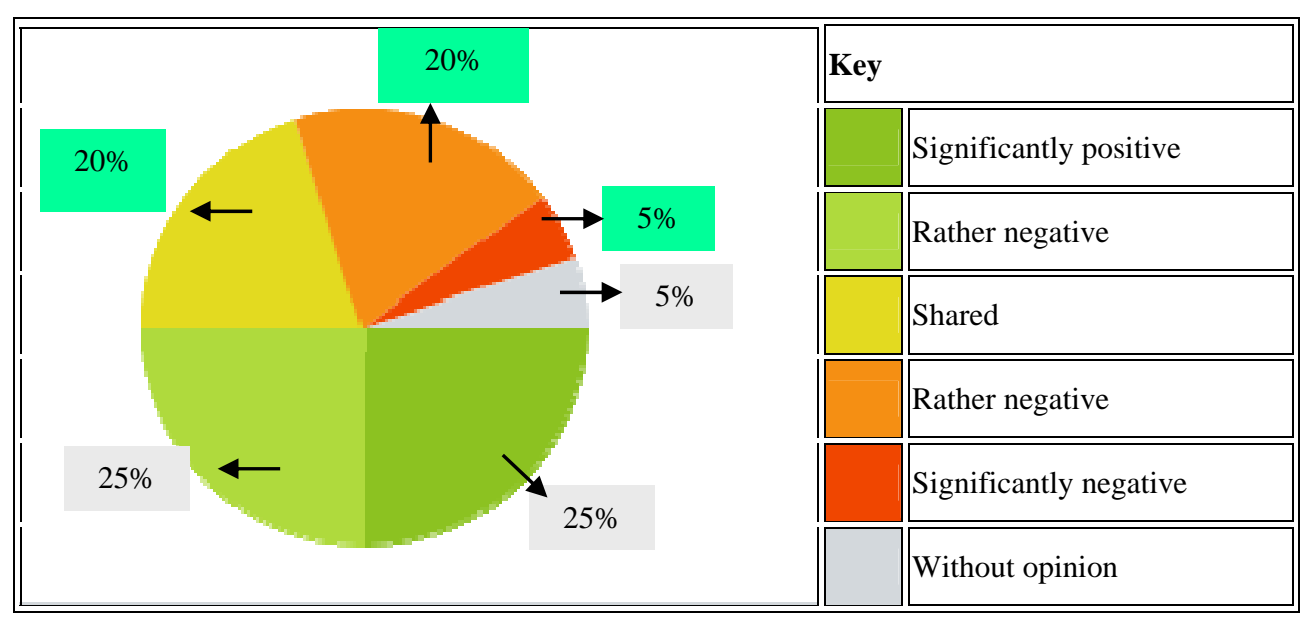

Figure 2. Characterization according to orientations and feelings.

Let's remind the concepts corresponding to level of concept 3. The richness of a corpus is the number of different words of the corpus. If the wealth index is superior to 1 , then the answers of that category are richer than the average. Conversely (index inferior to 1 ), the answers of this category are therefore less rich than the average.

In the analysis of concepts, the most significant answers to the orientation of feelings, to the characterization of predominant answers globally obtained to this effect are rather negative (1.21), significantly negative (1.21), and shared (1.13). The other feelings and orientations of answers such as significantly positive (0.90) and rather positive (0.87) tend to value 1 , but are not significant. In an attempt of generalization of results, it has been determined in the whole corpus opinions expressing a feeling, a judgment, or an evaluation relative to the real and effective influence of the inability to implement immediately the new SYSCOHADA uniform act and the IFRS international standards (articles 8 and 73.1) by the SMEs of African member states. Table 2 and its key above highlight the repartition of observations according to the orientations of positive or negative opinions they contain, by indicating the average size of the observations concerned as well as the words and contexts over-represented in each case, whose specific verbatim according to the orientation given ( in addition) gives examples of positive or negative opinions of interviews relative to the specific verbatim of that inability of accounting mutation from 1st January 2018. In the characterization according to the orientation, the table brings to the attention what characterizes the results. The specificities highlight the words, concepts, orientations, feelings, contexts, and thematic classes over-represented for each category of orientation. In the analysis per context, the 68 positive words specifically negative (particularly: lack, loan, January, equipment, will) against 45 positive words (such as: accounting, well, manager, information, accounting) are highlighted according to their context. The additions of opinions of individuals interviewed are given, according to the chronological order of the interviews relative to the specific verbatim of the inability of accounting mutation of African SMEs. The process starts with the obvious appearance of a percentage showing that the inability of accounting mutation rather explains a more negative than positive influence of accounting mutation as from 1st January 2018 of African SMEs.

\section{Discussions, Propositions, and Managerial Perspectives}

Discussions. In the field of production and use of accounting information, it is a matter of describing the answers of enterprises which have taken part in this study. Knowing the characteristics of these enterprises is 
essential to have a good understanding of factors likely to influence the quality of accounting information given. The quality of accounting information is assessed by the ability of these enterprises to reproduce a reality that is not distorted, neither by the perception and judgments, nor by the form that makes that reality intelligible (Michailesco, 2009). This quality depends on users and must answer the constraints of cost and time, from a double function assigned to the accounting information (a utilitarian and social function).

In this context, supporters of the evolutive perspective of accounting (Littleton, 1953; Belkaoui, 1984; 1985) have analyzed the phenomenon as "any social science that does not evolve according to a given process, but by means of a series of innovation”. This evolutivity observed in accounting since many decades is continuous. We draw inspiration from ideas and controversy raised by Kuhn (1970). In fact, according to this author, "any science has a cyclical life, in the sense that the importance of a theory is destroyed by the birth and establishment of a better one". On this basis, in relation to the uniform act of November 2000, "the plus" brought by the new uniform act of the OHADA accounting system of 15 February 2017, in parallel with IFRS standards (article 8 and 73-1) is just the continuation of that scientific reality in the current society. The ability of accountants and company managers to produce accounting information expected from the financial statements of the new accounting framework by the enterprise is an evidence of the increase of responsibilities of mangers in time and space; although, the ability and levels of production and use of accounting data reduce when the age of the manager increases (Begon, 1990; Lacombe, 1994).

As highlighted supra, this increase of managers' responsibilities can be done particularly by a regulatory and institutional reinforcement. The institutional and financial context of a company widely conditions the accounting policy of managers who are influenced by it (Parfet, 2000). The results of our study give some essential orientations. Firstly, the accounting staff in enterprises is not technically well equipped on the whole. Then, the difficulties of adoption of IFRS have enabled to better understand the expectations that we should have from accounting staff. Finally, accountants point the finger of scorn at their managers for the lack of necessary means to meet the requirements of adoption.

From the characteristics according to the above orientations and feelings, we deduce in terms of evolutivity predispositions that:

- The ability/inability to adopt the revised SYSCOHADA for a convergence to IFRS is expressed by feelings, orientations, and opinions essentially (and therefore significantly) negative.

- The organizational efficiency is influenced by the endogenous environment through variables such as lack of materials, accounting procedure, and professional qualification of accountants.

- Current events on accounting practice in OHADA space still vibrate intimately to the rhythms of the adoption of the new act revised in February 2017 and applicable as from 1st January 2018.

- The aptitude of adoption following the revisions of SYSCOHADA and the implementation of IFRS is certain but still far.

Propositions. Many elements show the weaknesses of the accounting organization in enterprises to the point of making the urgent implementation of a new uniform act difficult. That enables to have the opportunity to detect the problem which is among others the one of governance within entities. Thus, we can declare that:

- To implement a new uniform act in due date, company accountants must be technically equipped.

- Necessary material means must be put at the disposal of entity accountants.

- Company managers must obviously have the will to make accounting practice evolve in their company.

- Concrete actions shall be carried out in the majority of companies to face new standards. 
We therefore point out elements that show the weaknesses relative to the accounting organization in enterprises making the implementation of the new OHADA uniform act and IFRS standards difficult as from 1st January 2018. From the organizational and socioeconomic weakness indexes relative to the adoption of SYSCOHADA revised for its convergence towards IFRS and from the preceding, we propose that:

P1-the professional qualification of accountants has an impact on the practical adoption of SYSCOHADA in IFRS;

P2-the more company accountants have necessary provisions, the more effective the implementation of the new uniform act at due date shall be;

P3-the accounting involvement of company managers has an impact on the evolution of accounting practices;

P4-the adjustment ability of managers and accountants has an impact on the adoption of new accounting standards.

The normalizer should think about setting up an action plan. For the implementation of the new act, a well-established chronogram with levels of evolution of various activities would enable to anticipate and take corrective measures where necessary.

Managerial perspectives suggested. We notice in general that at the level of internal organization, nothing concrete has been done. To see at what level enterprises are, and seek more to know if accounting practice within these enterprises will be in accordance with the new OHADA uniform act, just a negligible part declares that it could produce financial statements in accordance with accounting standards in force. This is said by chartered accountants in the interviews. According to them, many company managers still cheat.

The evolution in accounting practice is a strong alarm. Company managers should be interested for more than one reason. Company managers must acquire good practices in the field of mutations, especially their implementation for an easy adjustment.

The normalizer should also draw lessons. In brief, all the actors of this process are supposed to learn from the way it has been thought, conducted, and implemented.

The respective governments must make people follow unscrupulously the chronograms defined, but beforehand, they must make sure that they are applicable in their context and therefore afterwards create an environment conducive to the implementation of the chronogram with permanent evaluations. The state must invest more in setting up informational devices, particularly by adapting the information to the evolution of the environment and the development of exchange. Given that, the level of states evolves and improves progressively in time. Accounting ethics for good corporate governance is also part of the basic elements of that accounting evolutivity.

\section{Conclusion}

Firstly, the analysis shows in the first position that the inability of accounting mutation OHADA-IFRS is essentially expressed by feelings, orientations, and negative opinions. In fact, the majority of accountants interviewed are mainly recruted on the basis of social ties. The presence of the manager or an accountant recruted in the company does not solve the problem of internal accounting practice as a whole; accounting is more entrusted to chartered accountants. Therefore it becomes indispensable to require refresher courses and training for accountants in order to face the deadline for the total or partial adoption of IFRS international accounting framework. 
The organizational efficiency of the internal accounting system SMSE is influenced by the endogenous environment through variables such as the lack of material, accounting procedure, and professional qualification of accountants. In other words, the internal accounting system within enterprises is not efficient because there exists a real problem of competenc as challenge in accounting evolution. For that, proposing abilities of accounting change constitutes solutions to the limits noted.

In fact, current events on accounting practice in OHADA space vibrates to the rhythms of the adoption of the new act revised in February 2017 and applicable as from January 2018. The subject of this study in the Cameroonian context is to analyze the ability of enterprises to produce accounting data following the revisions of the OHADA accounting system and the implementation of IFRS international standards. This problematic leads to look for the description of companies' predispositions to implement simultaneously the revised uniform act and IFRS international standards (articles 8, 73-1, and 75) by 1st January 2018. Let's remind that in order to understand it better, we asked some specific questions:

- Is the accounting personnel in enterprises well equipped?

- Do company managers have the necessary human and material resources at their disposal?

- Are managers willing to adopt the new OHADA and IFRS accounting deal?

- Are concrete actions carried out to face new standards?

These questions have enabled to analyze the opinions of corporate accountants intended to face change; to assess the predispositions taken by company managers to face this evolution in accounting practices; to seek to understand the ability to adjust to new accounting practices in their companies.

From the foregoing, the results obtained in relation to the theories mobilized and the questions asked are broken down into four essential orientations. Firstly, the accounting personnel in the enterprises is not well equipped on the whole. Then, the difficulties of adoption of IFRS international standards have enabled to better understand the expectations we should have from the accounting staff intended to carry out accounting tasks at the time of mutation. Finally, managers are indexed by corporate accountants in general who do not have the necessary material resources at their disposal to meet the requirements in due date.

\section{References}

Avelé, D., \& Degos, J.-G. (2014). Standardisation of international accounting: Harmonisation between OHADA and IASB (IFRS) reference frameworks. African J. Accounting, Auditing and Finance, 3(1), 27-47.

Ball, R. (2006). International Financial Reporting Standards (IFRS): Pros and cons for investors. Accounting and Business Research, International Accounting Policy Forum, 36(1), 5-27.

Bampoky, B. (2016). Une histoire complète des difficultés de normalisation comptable OHADA: Plaidoyer pour un normalisateur adapté. 1ère Journée d'Etude Africaine en Comptabilité et Contrôle (JEACG). 14-15 décembre, Dakar.

Barth, M. E., Landsmann, W. R., \& Lang, M. H. (2007). International accounting standards and accounting quality. Journal of Accounting Research, 46(3), 467-498.

Bégon, G. (1990). Le système d'information de synthèse dans les PME: Un marché. Mémoire d'Expertise Comptable: 98.

Belkaoui A.R. (1984). Théorie comptable, Presse de l'université du Québec, Canada.

Belkaoui, A.R. (1985). International Accounting: Issues and Solutions, Quorum Books.

Benjamin, N., \& Mbaye, A. A. (2012). The informal sector in Francophone Africa: Firm size, productivity and institutions. Washington, DC: World Bank.

Burchell, S., Clubb, C., Hopwood, A.G. (1985). Accounting in its social context: towards a history of Value added in the United Kingdom. Accounting Organizations and Society, 10(4), 381-413.

Causse, G., \& Wa Mandzila, E. E. (2016). Les normes comptables internationales: Facteur de développement économique, effet de mode, ou "cheval de Troie”? Application aux pays de l'OHADA. 1ère Journée d'Etude Africaine en Comptabilité et 
Contrôle (JEACG), 14-15 décembre, Dakar.

Cormier, D., Magnan, M., \& Morard, B. (1998). La gestion stratégique des résultats: Le modèle anglo-saxon convient-il au contexte Suisse? Comptabilité-Contrôle-Audit, 4(1), 25-49.

Daske, H., Hail, L., Leuz, C., \& Verdi, R. (2008). Mandatory IFRS reporting around the world: Early evidence on the economic consequences. Journal of Accounting Research, 46, 1085-1142.

Degos, J.-G., \& Souleymanou, K. (2016). Changement de paradigmes de la comptabilité financière pour une meilleure gouvernance des entreprises. Revue du FINANCIER, 221(38), 45-71.

Degos, J.-G., \& Souleymanou, K. (2018). Révision de l'acte uniforme SYSCOHADA: À l'heure de l'adoption des normes IFRS dans les structures informelles des états parties? Revue du FINANCIER, 228-229(39-40), 50-73.

De Boissieu, C. (2002). Faut-il tout dire, tout le temps? Sociétal, (37), 76-80.

D’Souza, J. (1998). Rate regulated enterprises and mandated accounting changes: The case of electric utilities and post-retirement benefits other than pensions (SFAS 106). The Accounting Review, 73(3), 387-410.

Dumontier, P., \& Raffournier, B. (1993). Vingt ans de recherche positive en comptabilité financière. Comptabilité-Contrôle-Audit, 5(3), 179-197.

Dutta, S., \& Gigler, F. (2002). The effect of earnings forecasts on earnings management. Journal of Accounting Research, 40(3), 631-655.

Dyer, J. G. W., \& Wilkins, A. L. (1991). Better stories, not better constructs, to generate better theory: A rejoinder to Eisenhardt. Academy of Management Review, 16(3), 613-619.

Eisenhardt, K. (1989). Building theories from case study research. Academy of Management Review, 14(4), 532-550.

Eisenhardt, K. M. (1991). Building theories from case study research. Academy of Management Review, 16(3), 620-627.

Feudjo, J. R. (2010). Harmonisation des normes africaines et internationales: Une urgence ou une exigence? La Revue des Sciences de Gestion, Direction et Gestion, 5-6(245-246), 149-158.

Gilman, S. (1939). Accounting Concepts of Profit. New York: Ronald Press Co.

Gioia, D. A., Corley, K. G., \& Hamilton, A. L. (2013). Seeking qualitative rigor in inductive research: Notes on the Gioia methodology. Organizational Research Methods, 16(1), 15-31.

Gordon, L. A., Loeb, M. P., \& Zhu, W. (2012). The impact of IFRS adoption on foreign direct investment. Journal of Accounting and Public Policy, 31, 374-398.

Hatfield, H. R. (1927). Accounting, Its Principles and Problems, New York: D. Appleton and Co. Reprinted 1971 by Scholars Book Co., Lawrence, Kan.

Hendriksen, E. S. (1982). Accounting Theory, Homewood, Illinois, Richard, D. Irwin Inc.

Hernandez, E.-M. (1999). Aspects financiers et comptables de l'entreprise informelle africaine. Revue Gestion, 24(1), 68-76.

Hopwood, A. G. (1972). An empirical study of the role of accounting data in performance evaluation. Empirical Research in Accounting: Selected Studies. Supplement to Journal of Accounting Research, 10, 156-193.

Hopwood, A. G. (1973). An accounting system and managerial behaviour. Brooksville, Florida: Saxon House.

Hopwood, A. G. (1974). Accounting and human behaviour. New Jersey: Prentice Hall Inc.

Hopwood, A. G. (1976). The path ahead. Accounting, Organizations and Society, 1(1), 1-4.

Hopwood, A. G. (1983). On trying to study accounting in the contexts in which it operates. Accounting, Organizations and Society, 8(2/3), 287-305.

Hopwood, A. G. (1987). The archaeology of accounting systems. Accounting, Organizations and Society, 12(3), 207-234.

IASB. (2010). Annual report: Financial reporting for the world's interconnected financial markets. London: IFRS Foundation.

Jonas, G. J., \& Blanchet, J. (2000). Assessing quality of financial reporting. Accounting Horizons, 14(3), 353-363.

Kuhn, T.S. (1970). The Structure of Scientific Revolutions, 2nd edition. Augm., International Encyclopedia of Unified Science, Chicago, University of Chicago Press.

Labelle, R., \& Touron, P. (2001). Le potentiel de l'étude de cas comme méthodologie de recherche en comptabilité financière. In Faire de la recherche en comptabilité financière (pp. 117-136). Vuibert Fnege.

Lacombe-Saboly, M. (1994). Les déterminants de la qualité des produits comptables des entreprises: le rôle du dirigeant. Thèse de doctorat en Sciences de Gestion, Université de Poitiers.

Lenormand, G., \& Touchais, L. (2009). Les IFRS améliorent-elles la qualité de l’information financière? Approche par la value relevance. Comptabilité-Contrôle-Audit, 15(2), 145-163.

Littleton, A. C. (1953). Structure of accounting theory, American Accounting Association, Monograph No. 5.

Levitt, A. (1998). The importance of high quality accounting standards. Accounting Horizons, 12(1), 79-82. 
Littleton, A. C., \& Zimmerman, V. K. (1962). Accounting theory: Continuity and change. Englewood Cliffs, N.J.: Prentice-Hall.

Mballa, A. Y. V. (2016). La production de l'information comptable au sein des entreprises camerounaises: Vers l'urgence d'une réforme institutionnelle? Revue de Management et de Stratégie, 3(2), 48-77.

Ménard, L. (2011). Dictionnaire de la comptabilité et de la gestion financière (3rd edition). Canada: FCA.

Michallesco, C. (2009). Qualité de l’information comptable. In Encyclopédie de Comptabilité, Contrôle de gestion et Audit, Economica (pp. 1023-1033). Retrieved from https://halshs.archives-ouvertes.fr/halshs-00540571/document

Miles, M., \& Huberman, A. M. (1994). Qualitative data analysis (2nd ed.). Thousand Oaks, CA: Sage Publications.

Murphy, A. B. (1999). Firm characteristics of Swiss companies that utilize international accounting standards. International Journal of Accounting, 35(1), 121-131.

Ngantchou, A. (2011). Le Système Comptable OHADA: Une réconciliation des modèles “européen continental” et “anglo-saxon”? Comptabilité-Contrôle-Audit, 17(3), 3-54.

Nobes, C. (1998). Towards a general model of the reasons for international differences in financial reporting. Abacus, 34(2), 162-187.

Otley, D. (1978). Budget use and managerial performance. Journal of Accounting Research, 16(1), 122-149.

Parfet, W. (2000). Accounting subjectivity and earnings management: A preparer perspective. Accounting Horizons, 14(4), 481-488.

Penouil, M. (1998). La transition de l'activité informelle à la P.M.E. est-elle possible? n 23, Centre d'Économie du Développement. Paris: Université Montesquieu-Bordeaux IV.

Recensement Général des Entreprises (2018). Rapport préliminaire des principaux résultats, édition de janvier, 45.

Richard, J., \& Collette, C. (2008). Comptabilité générale Système français et normes IFRS (8th ed.). Paris: Dunod.

Rispal, H. M. (1993). Les modes de création et de fonctionnement d'accords de coopération (AC) transnationaux entre dirigeants de PME-PMI européens: Une analyse qualitative inductive (Thèse de doctorat nouveau régime en sciences de gestion, Université de Bordeaux I).

Schevin, P. (2010). Comptabilisation des contrats de location en normes IFRS: L’IAS 17 et le projet de réforme. Revue Française de Comptabilité 428:20-25.

Schipper, K., \& Vincent, L. (2003). Earnings quality. Accounting Horizons, 17, 97-110.

Souleymanou, K. (2010). La pertinence de l'information comptable produite par les états financiers dans les entreprises camerounaises: Une comparaison du plan OCAM et du système OHADA (Thèse en sciences de gestion, Université de Ngaoundéré).

Souleymanou, K. (2011). Dix ans de mise en application du système comptable OHADA dans les pays en voie de développement, les difficultés d'adoption des normes comptables internationale: Le cas du Cameroun. Revue du Financier, 189, 81-85.

Souleymanou, K., \& Halidou, M. (2014). Assessment of the relevance of accounting mutations: An analysis from financial statements in Cameroon. African J. Accounting, Auditing and Finance, 3(1), 67-81.

Souleymanou, K., Djekaye, J.-L., \& Hikkerova, L. (2016). Qualité informationnelle des agrégats comptables et décisions financières des PME africaines non cotées: Cas du Cameroun. Revue Gestion, 4(33), 143-158.

Van Tendeloo, B., \& Vanstraelen, A. (2005). Earnings management under German GAAP versus IFRS. European Accounting Review, 14(1), 155-180.

Watts, R. L., \& Zimmerman, J. L. (1978). Towards a positive theory of the determination of accounting standards. The Accounting Review, 53(1), 112-134.

Yin, R. (1994). Case study research: Design and methods (2nd ed.). Beverly Hills, CA: Sage Publications.

Zimmermann, J., \& Gontcharov, I. (2003). Do accounting standards influence the level of earnings management? Evidence from Germany. Cahier de recherche, London Business School. 


\section{Appendix}

Appendix A: Interview Guide with Accountants and Executives

Tell us about the structure you work for

Theme 1: Level of qualification in accounting

- School travel

- Additional training

- Professional experience Training

Theme 2: Working tools to adopt the new Uniform Act OHADA and IFRS

- Manual of accounting and financial procedures within your company

- Documentation to help you to adapt to the evolution of accounting practice

- Existence of an automated accounting information management application

Theme 3: Will of the leaders companies to evolve the quality of accounting information within their structure

- Development policy of your technical capabilities

- Evaluation system/stimulation of your accounting performance

- Working environment compared to the accounting information production system

Appendix B: Interview Guide with Accounting Experts

Theme 1: Quality of accounting practices judged within companies

- Level of accountants you meet in business

- Level of professional experience of accountants

- Professional capacity of accountants to use essential tools for the transition of companies to new Uniform Act and IFRS standards

Theme 2: The ability of accountants

- The accountants of the companies you work with have the tools they need for good accounting practice

- Updated documentation on the evolution of accounting practice.

Theme 3: Willingness of business leaders to change the quality of accounting information within their structure

- Policy for the development of staff capacity within companies

- Existence of a system for evaluating performance within companies

- Working environment in relation to the system of production of accounting information

Table 5

Feelings Analyzed (Evaluation, Hiring, Interest of Respondents)

\begin{tabular}{lll}
\hline & Positive & Negative \\
\hline Length & 45 words & 68 words \\
& accounting & lack \\
Specific words & good & ready \\
& leader & january \\
& information & tool \\
Specific contexts & accounting & will \\
\hline
\end{tabular}


Table 6

Opinion on the Capacity of Cameroonian Companies to Submit Their Accounting Data in Accordance With the Uniform Act OHADA to 1st January 2018

\begin{tabular}{|c|c|c|c|}
\hline Case & Technical capabilities & Hardware availability & Will of the leader \\
\hline 1 & No & No & No \\
\hline 2 & Yes & No & Yes \\
\hline 3 & No & No & No \\
\hline 4 & Yes & No & No \\
\hline 5 & Yes & Yes & No \\
\hline 6 & No & No & No \\
\hline 7 & No & No & No \\
\hline 8 & No & No & No \\
\hline 9 & No & No & No \\
\hline 10 & No & No & No \\
\hline 11 & No & No & No \\
\hline 12 & No & Yes & No \\
\hline 13 & No & No & No \\
\hline 14 & Yes & Yes & Yes \\
\hline 15 & No & No & No \\
\hline 16 & No & Yes & No \\
\hline 17 & No & No & Yes \\
\hline 18 & No & No & No \\
\hline 19 & No & No & No \\
\hline 20 & No & No & No \\
\hline
\end{tabular}

